\title{
ЈАСНА ВЛАЈИћ-ПОПОВИЋ
}

\section{ЈСЛ. ЗеЗати (се) - ЛЕКСИКОГРАФСКО СИРОЧЕ ИЛИ ЛЕГИТИМНА ОДРЕДНИЦА}

\section{Coвiss: 1.01}

\begin{abstract}
Jsl. zezati (se) - leksikografska sirota ali legitimno geslo
V delu se potrditve glagola zezati (se) 'šaliti se (nevtralno ali grobo)', zast. pokr. 'mrdati, koitirati itd.' z izpeljankami, ki se nahajajo v slovenskih in srbsko-hrvaških slovarjih, semantično klasificirajo, ob pregledu onomazioloških paralel, ustreznikov v drugih slovanskih jezikih in obstoječih razlag izvora, s predlogom, da se do kompletiranja slovanskega gradiva etimologija te onomatopejske družene besed vseeno šteje za nejasno.

Ključne besede: slovenščina, srbščina in hrvaščina, etimologija, onomaziologija, onomatopeja
\end{abstract}

\section{South Slavic zezati (se): a lexicographic orphan or a legitimate lemma}

This article deals with the verb zezati se 'to kid around (neutrally or rudely)', obsolete regional 'to stir, jerk, wriggle; fuck, etc.' and its derivatives, whose attestations in Slovenian and Serbo-Croatian dictionaries are subjected to semantic classification. Reviewing its onomasiological parallels, Slavic counterparts, and the etymology leads to the proposal that, until more Slavic data are obtained, the etymology of this onomatopoeic word family should be considered uncertain.

Keywords: Slovenian, Serbo-Croatian, etymology, onomasiology, onomatopoeia

\section{0 УВОД}

Повод за бављење глаголом zezati (se) / зезати (ce) 'шалити се (неутрално и(ли) грубо)', ‘замајавати (се)' итд., била је дилема око тога да ли он треба да уђе у Приручни етимолошки речник српског језика $\mathbf{1}$ или не. Та иницијално нормативистичка недоумица отворила је праву малу Пандорину кутију питања из домена историје речи, социолингвистике, ареалне лингвистике, ономасиологије, а на крају и етимологије. Показало се да је глагол zezati (se) / зезати (се) посведочен само на словенском југозападу: релативно ограничено у словеначком језику и прилично добро на читавом српско-хрватском терену. У оба језика постоји семантичка подвојеност између савремених

Чланак је настао као резултат рада на пројекту бр. 178007 „Етимолошка истраживања српског језика и израда Етимолошког речника српског језика“ који у целини финансира Министарство просвете, науке и технолошког развоја Републике Србије.

1 Нешто више о концепцији тог речника, који у принципу обухвата само основни лексички фонд српског језика, в. Бјелетић - Влајић-Поповић 2013. 
стандардних потврда (иначе уједначених значења на читавом простору од Алпа до бугарске границе), и оних старијих и/ли дијалекатских (које показују неке локалне специфичности). Савремена значења интранзитивних облика су 'шалити се, проводити се и сл.', а транзитивних 'задиркивати; подваљивати, кињити'. Оваква семантика, као и фонетски лик који указује на ономатопеју, глагол zezati (se) / зезати (ce) у оба језика смештају на маргину стандардне употребе, у зону колоквијалног регистра - чак нижег стила - што га чини наизглед незанимљивим за етимологисање. Међутим, прве потврде, још са почетка односно краја претпрошлог века, мењају перспективу јер уводе и друга значења - као и на њима базиране именске изведенице - што указује на постојање читаве породице речи вредне разматрања.

\section{1 ЛЕКСИКОГРАФСКА ПОСВЕДОЧЕНОСТ}

1.1 Лексикографска посведоченост у оба језика показује необичан дисконтинуитет. У словеначком глагол zézzati (se) прво добро документуje Pleteršnik 18952 у значењу 'migati [мрдати, кретати се тамо-амо]' 3 После паузе од готово читавог века садржи га, само у значењу 'завитлавати', нпр. Slovensko-srbskohrvatski slovar (Jurančič 1981), па затим тек најновији Slovar novejšega besedja slovenskega jezika (SNB 2013) - овај други са напоменом да се ради о позајмљеници из хрватско-српског. Велики Slovar slovenskega knjižnega jezika (SSKJ 5, 1991) уопште не региструје овај глагол, јер он не спада у књижевни стандард, 4 а не садрже га ни новији дијалекатски речници.

1.1.1 Не доноси га Slovenski etimološki slovar M. Snoja (пошто не припада основном лексичком фонду на који је ограничен захват тог речника). Међутим, одговарајућу одредницу садржи Bezlaj (4, 2005: 407, где су у обзир узети примери које доноси Pleteršnik и грађа SSKJ). Више о томе у $§ .1$.

1.2 У српском, тј. српско-хрватском ситуација је сложенија. Најстарији помен у првом издању Вуковог Српског рјечника из 1818. доноси значење 'futuere', и само њега. Та је чињеница кобно утицала на даљи лексикографски третман овог глагола: током наредних сто педесет година имао је судбину лексикографског сирочета, подвргнутог својеврсној damnatio memoriae - већ сам Вук га је изоставио из другог издања свог речника (па

2 Међу изворима за ту одредницу налазе се рукописи (из претходних пар деценија): M.[iklošičevo slovarsko gradivo], Z.[alokarjev slov.-nemški slovar], C.[afovo slovarsko gradivo], Raič [Slovanstvo: Bolgari in drugi spisi].

3 Ту су и основни деривати: zẹ́zanje n. 'slabo, obotavljajoče delo', zẹ́za-mộž, zẹ́zavac m. 'slaba oseba', zézavka f. 'Motacilla alba', zẹ́za 'id.; zadek pri perutini'.

4 У његовој грађи је ипак постојала дијал. потврда значења 'brcniti, suniti', у народној песми из Штајерске и књиж. zezej 'neodločnež, pokveka' (в. Bezlaj 4: 407). 
тиме и из свих потоњих), а касније су то листом чинили и други аутори, чак и уредници великих речника у чији захват иначе улази Вук 1818.5 Тако је јасно да опсцено значење није било део само Вуковог родног говора, на основу кога је он саставио прво издање Српског рјечника, већ је имало много шири ареал.

1.2.1 Тек у другој половини XX века, када опсцено значење почне да бледи пошто се у масовној употреби увелико усталило од њега изведено 'шалити се, зафркавати се', глагол зезати (се) напокон улази у описне речнике. Обавезно присутни квалификатор ,вулг.“ сведочи да је код лексикографа и даље присутна свест о његовом „неприличном“ значењу.6 Тако је у Речнику српскохрватског књижевног језика (РМСМХ 2, 1967 - са примером из дела О. Давича). Потом одговарајући том Речника српскохрватског књижевног и народног језика (РСАНУ 6, 1969) доноси значење 'зафркавати (се)' - само као редакцијски пример, док нешто касније Rječnik hrvatskoga ili srpskoga jezika (RJAZU 22, 1975) такво значење уопште нема. Затим га, и само њега, доносе Anić (2003) и РС (2007) - али оба га више не квалификују као вулгарну реч већ као колоквијалну (конкретно разг.[оворно], другде и шатр.[овачки], жарг.[онски], в. доле). ${ }^{7}$

1.2.2 Међутим, два тезаурусна описна речника, PCAHУ и RJAZU, садрже грађу са терена, покрајинску, сакупљану много пре публиковања одговарајућих томова, где су посведочена значења 'мрдати, трести, дрмусати и сл.', као и неке њихове изведенице - управо као код Плетершника век раније - и то са широког простора од Лике, Баније, Брача, Дубровника, Злакусе, Груже до Ниша. На те описне речнике надовезују се неки 8 новији дијалекатски (кајкавски, чакавски, из Црне Горе, југоисточне Србије, Војводине) који шире дијапазон потврда из описних речника и додатно документују постојање у РСАНУ и RJAZU први пут регистрованих соматонима и орнитонима зёз(a), зѐза̄љка и сл. Опсцено значење и даље подлеже својеврсној (ауто)цензури: РСАНУ га

$5 \quad$ \Zezati, otkud ime zezi tresorepki, kojega je Vuk u drugoj štampi svojega slovnika ispustio, primisliv mu znamen bludan« Kurelac (RJAZU).

6 Да је оно, иако лексикографски нерегистровано, ипак доминирало у свести говорника познато нам је и из личног искуства са старијим рођацима.

7 Иако је глагол у два основна значења 'зафркавати (се), шалити се' и 'малтретирати, надмудривати, нервирати', и са низом изведеница и фразеологизама, богато заступљен у специјализованим речницима српског тј. хрватског жаргона (в. најрепрезентативније међу њима, Андрић 77 и Sabljak 160), тамо постојећи инвентар облика и значења остаје ван нашег тренутног интересовања: те потврде одсликавају животност савременог социолекта а не доприносе попуњавању дијахроне и/ли дијалекатске слике творбено-семантичког развоја разматраног глагола и његове лексичко-семантичке породице.

8 У богатој продукцији таквих речника овог глагола или нема, или он стоји у стандардним значењима неутралисане опсцености. 
уопште нема,9 док RJAZU не преноси директно Вукову одредницу из 1818. године већ за њено „просто“ значење цитира Курелца (в. нап. 5) и упућује на синонимно „mrdati d.“.

1.2.3 Право изненађење представља потпуно одсуство глагола zezati (se) / зезати (се) из Etimološkog rječnika hrvatskoga ili srpskoga jezika (в. Skok 3, 1973, односно његова Kazala, Skok 4, 1974), пошто Петар Скок није примењивао ванлингвистичке критерије у избору одредница.10 Помињање овог глагола у специјализованом речнику Jadranske etimologije (Vinja 3, 2004 s.v. zèzalo) за етимологисање је фактички ирелевантно јер се, сходно профилу тог речника, ту говори само о малакониму који је тек једна од изведеница глагола zёzati ‘мрдати, трести’ (в. § 2.7.3).

\section{2 Семантика}

Семантичко језгро породице речи чини значење 'мрдати'. Даље се оно развија у више праваца, ка различитим аспектима кретања тамо-амо или горе-доле (првенствено деловима тела - отуд нпр. nomen instrumenti 'тртица' и nomen agentis 'плиска' или 'мали јастог') односно варијантама мрдања, дрмусања при вожњи колима, јахању, игрању тј. поскакивању у колу. Отуд се развијају пренесена значења, конкретно 'futuere' и апстрактно 'шалити се (неутрално или грубо)', отуд даље 'кињити, подваљивати и сл.' . Тренутни вид даје и значење 'ударити, треснути' (поред 'преварити'). Ономатопеја се из сфере кретања може пренети на звук који се производи учестаним кретањем. У попису који следи све потврде из репрезентативних речника са терена словенског југозапада (в. $§ 1.1-1.2 .3$ ) наводе се груписане по значењима,11 приказане на једном месту независно од језика и/ли дијалекта коме припадају.

\section{1 'МРДАТИ'}

слн. zézzati, -ām impf. = migati '(sich) hin und her bewegen' M., Z., C., Raič (Vest.); - prim. hs. gegati = gugati (Pleteršnik 1895)

слн. zẹ́zniti, zệznem pf. 'eine hinkende Bewegung machen' Z. (Pleteršnik 1895)

c.-х. чак. zёzot, zёzon, ipf vn lit zezati 'wabbeln, wackeln, wippen (v. Fett, Busen u. ä.) Mandina sva zezo kal balo. Dračevica na Braču (ČDL)

9 Мало необично за доба у коме излази (1959. до данас), тај врло пуритански профилисани речник књижевног и народног језика не садржи ни одреднице као говно, дупе, кураи и сл.

10 Он има, нпр. одредницу jebati (Skok 1: 765). Да ли је Скок сматрао глагол безначајним, па га није ни потражио у картотеци RJAZU (којом се иначе обилато користио у обради речи на слова која још нису била објављена), или је по среди био неки други разлог - остаје неизвесно.

11 Глаголи долазе пре изведеница; глаголске именице наводе се само када нема глагола у истом значењу, или када су илустроване добрим примером. 
c.-х. чак. zёzot, zëzon, ipf vn lit zezati 'podrhtavati, njihati (zbog debljine, jakih grudi, stražnjice i sl.’ [са истим примером из Драчевице] (Šimunović 2006)

c.-х. зёзати, - $\bar{a} м$ несвр. 'трескати, дрмусати при вожњи': Кад кола, возећи преко рђава пута, јако тресу, рећи ће: „О, ала та кола зезају, испашће ми утроба!“ Банија; 'брзо се покретати горе-доле, поскакивати, љуљати се': Зезати значи поскакивати сједећи на пример на коњу ; Шта си напа ту зезати? Лика, Банија, Злакуса (РСАНУ)

c.-X. zëzati, -ām impf. 'micati, tresti'. Zezati, otkud ime zezi tresorepki, kojega je Vuk u drugoj štampi svojega slovnika ispustio, primisliv mu znamen bludan. Kurelac dom. živ 51. [...] Zezati repom, mit dem Schwanze wippen, caudam motitare (u Matevcu kod Niša u Srbiji); isto je klatiti, vrckati 1, vrtljati (RJAZU)

c.-х. зёза̄mu, - $\bar{a} м$ несвр. 'Покретати тамо-амо нешто што је чврсто пободено и што треба да се извади’: Зезај тијем коцем нели га рашкламитати! Ускоци (Станић 1990)

c.-х. sésa несвр. ‘поклецује играјући у колу' Тимок (Кожељац 2014)

c.-x. zèzānje nom. verb. od zezati 'micanje, pomicanje' (RJAZU)

c.-х. sésaњe c. 'поклецавање при игрању у колу': С оној sesaње он би да сви у њег гледају. Тимок (Кожељац 2014).

\section{2 'УДАРИТИ, ТРЕС(НУ)ТИ'}

слн. zẹ́zniti pf. 'brcniti, suniti': Ali je ta mačka vaša, ki mi je zeznola v rit? народна песма из Штајерске (грађа SSKJ, в. Bezlaj 4: 407)

с.-х. зёзнути, -нём свр. покр. 'дрмнути, протрести' Лика (РСАНУ)

c.-х. zëzati, -ām impf. ['тући (конопљу)'] ... U Vrbovskom žene i djevojke cibaju na tukači, t.j. tuku, zezajuće, konoplje na stupi. Kurelac (RJAZU)

c.-Х. зёзнути, -неем свр. 'Ударити, треснути': Зезнуо е главом о камен. Ускоци (Станић 1990).

\section{3 'КОИТИРАТИ'}

c.-х. зѐзати, -а̄м impf. 'sich schwingend bewegen, agitari futuendo' (Вук 1818)

c.-Х. зѐзнути pf. 'eine schwingende Bewegung machen, agitari futuendo' (Вук 1818)

c.-Х. чак. zezúkati impf. dem. od zezati. S istim opscenim značenjem zabilježio na Braču Ostojić (RJAZU)

c.-X. zëzati, -ām impf. 'micati, tresti' [...] U istočnim krajevima ima taj glagol prosto [тj. вулгарно] značenje kao i mrdati pod d. Takvo je značenje s akc. zèzati zabilježio i Ostojić na Braču. Zezati repom, mit dem Schwanze wippen, caudam motitare (u Matevcu kod Niša u Srbiji); isto je klatiti, vrckati 1, vrtljati (RJAZU)

c.-х. sésa несвр. 'мрда задњицом напред-назад у полном чину (женски партнер)’ Тимок (Динић 1992; Кожељац 2014)

c.-х. зеза̂ңе n. 'eine Art schwingender Bewegung, agitatio futuentis' (Вук 1818). 


\section{4 'НАПОРНО, С МУКОМ, ЛОШЕ РАДИТИ'}

слн. zẹ́zanje n. 'säumiges, zögerndes Thun' Raič (Vest.) (Pleteršnik 1895)

слн. zézza-mộž m. = zẹ́zavec Raič (Vest.) (Pleteršnik 1895)

слн. zézzavac m. 'ein säumiger Mensch' Raič (Vest.) (Pleteršnik 1895)

c.-х. зѐзеритти, -йм несвр. 'напорно ићи', 'напорно радити'12 Ускоци (Станић 1990)

c.-х. s'ssmbн м. 'онај који је лењ, здепаст и дебео; готован’ Тимок (Динић 2008).

\section{5 'ПРЕВАРИТИ, ПОДВАЛИТИ', 'КИњИТИ, МУЧИТИ'}

слн. zêzati pog. 'namerno povzročiti komu neprijetnosti, težave': Nazaj grede nas vedno zezajo na carini. (SNB 2013)

c.-х. кајк. zęznóti (se) pf. 'prevariti (se)': Štel me je zeznoti: Baš sem se dobro zeznol. Gola (Večenaj - Lončarić 1997)

c.-х. кајк. zeznuti (se) pf. 'prevariti (se)' Varaždin (Lipljin 2002)

c.-х. зёзнути, -нём сврш. вулг. 'намагарчити, преварити, подвалити’ Давичо, ce 'преварити се, претрпети неуспех' (РМСМХ)

с.-Х. зёзати, -а̄м несвр. (некога) вулг. 'подвалити некоме, насамарити' Хам; Војводина (РСАНУ)

с.-х. ѝзезати, - $\bar{м}$ свр. вулг. 'накињити, измучити грубим шалама или злобним поступцима': Ће ме изеза, па таг ће дадне. Момина Клисура (РСАНУ)

c.-x. zëznuti svrš. razg. 'prevariti (se), zafrknuti (se)' (Anić 2003)

c.-х. зёзнути разг. ‘преварити (некога), подвалити (некоме)’ (РС 2007)

с.-х. зёзнути, -нём свр. 'Учинити некоме нешто непријатно; обманути, преварити, насамарити' Ускоци (Станић 1990)

с.-х. зёзнути несвр. 'подвалити некоме, преварити некога' Ново Милошево (РСГВ)

c.-Х. зеззне свр. 'завркне [превари]': Зезну ме, не дојде да ми помогне. Каменица код Ниша (Јовановић 2004)

с.-х. зезз м. 'подвала' Ново Милошево (РСГВ)

c.-х. sésнym, -a, -о 'преварен, насамарен, зафркнут' Тимок (Кожељац 2014)

c.-х. кајк. zeznuti adj. 'koji je teške naravi' Varaždin (Lipljin 2002)

c.-х. чак. zëzalo n. 'zanovijetalo’ Pučišća na Braču (Šimunović 2006).

\section{6 'ЗАФРКАВАТИ (СЕ)'}

слн. zézati razg. 'zavitlavati, izvrgavati šegačenju': kaj me zezaš? (Jurančič 1981)

слн. zêzati pog. 'dražiti koga, norčevati se iz koga': V kantini igrajo karte in zezajo natakarice. (SNB 2013)

c.-х. чак. zёzot, zëzon, ipf vn lit zezati 'zafrkavati, izrugivati, praviti šale na čiji račun’ Dračevica na Braču (Šimunović 2006)

c.-х. чак. zёcati imprf. 'zadirkivati, šaliti se na čiji račun' Kukljica na Ugljanu (Vinja 3: 321)

12 Овамо вероватно не спада значење ‘бдети, чекати, дреждати’ (Станић 1990). 
с.-х. зёзати, -̄̄м несвр. вулг. 'завитлавати, извргавати шегачењу', ce 'завитлавати се, шегачити се’ (РМСМХ)

с.-х. зёзати, -а̄м несвр. ce вулг. 'понашати се неозбиљно, измотавати се' (РСАНУ); на̀зезати свр. се 'издовољити се збијајући грубе шале с неким, завитлавати некога'; Са’т ти је паднуло уруке па ми се назезај. Момина Клисура (РСАНУ)

c.-X. zëzati nesvrš. razg. 'zavitlavati (se), šaliti (se), zafrkavati (se)' (Anić 2003)

c.-х. зёзати, -̄̄м несвр. разг. 'збијати грубе шале, завитлавати' (РСЈ 2007)

c.-Х. зёза̄ти несвр. шатр. 'збијати неукусне, грубе шале с неким, злонамерно, простачки поступати према некоме, завитлавати некога'; ce 'неозбиљно се понашати, измотавати се', 'непристојно, грубо се шалити на рачун једног према другоме, завитлавати један другога’ Ускоци (Станић 1990) с.-х. зёзати се несвр. 'зафркавати се' Ново Милошево (РСГВ)

c.-Х. зезза кризу изр. жарг. 'зајебава се, шегачи се, неозбиљно се понаша, спрда ce’: Не зезај кризу, бре, озбиљи се! Тимок (Кожељац 2014)

c.-х. sésa несвр. 'зеза, зајебава се; завитлава се, шали се’ Тимок (Кожељац 2014)

c.-Х. зезза (се) несвр. 'завркава': Зезају га у здрав мозак; Мангупарија, зеза се сас стари људи. Каменица код Ниша (Јовановић 2004)

с.-х. кајк. zezanje n. 'zadirkivanje, šala' Varaždin (Lipljin 2002)

с.-х. зезз м. 'досетка, шала' Ново Милошево (РСГВ)

с.-х. кајк. zezancija f. 'zabava, lak posao' Varaždin (Lipljin 2002)

c.-x. zezàncija ž. 'situacija kada se u društvu međusobno zeza' (Anić 2003)

c.-х. зеза̀нција ж. разг. 'збијање шале, завитлавање’ (РС 2007)

c.-х. зѐза̄нциंа ж. вулг. 'излагање некога тешком вређању, завитлавању и сл., зезање’ Ускоци (Станић 1990)

с.-х. зеза́ничија ж. ‘зезање, измотавање’ Тимок (Кожељац 2014)

c.-х. зѐзант м. 'зафркант’ Нови Сад (РСГВ).

\subsection{1 'ТРТИЦА'}

слн. zéza f. 'der Steiß des Geflügels’ C., purja, gosinja, račja, kokošinja z., Vest. (Pleteršnik 1895)

c.-Х. зёз м. покр. 'тртица у перади' Курелац (РСАНУ)

c.-X. zez m. 'trtica'. U peradi se trtica zove zez. Kurelac 1867 (RJAZU)

c.-X. zezak= zez m. 'trtica, os coccygis'; Steiss, Rürzel (RJAZU)

c.-х. зѐза̄љка ж. 'доњи део кичме у којем се најчешће осети бол' Ново Милошево (РСГВ).

2.7.2 'ПЛИСКА' = 'Motacilla alba' (alias дркорепа, маширеп, позезула, репомига, mресорепка, итал. batticoda, codatremula, в. РCAHУ, RJAZU, Vinja s.vv.).13

13 Уп. и локални назив цицигуз 'водени кос, Cinclus cinclus' Горња Колубара (Александар Лома забележио 1976. године) за птицу која такође карактеристично - али не тако интензивно као плиска - маше репом. 
слн. zẹ́za f. 'die Bachstelze' C. (Pleteršnik 1895)

слн. zézzavka f. 'die Bachstelze' C. (Pleteršnik 1895)

c.-х. зёза ж. покр. зоол. 'бела плиска, Motacilla alba' Курелац (РСАНУ)

c.-х. зёзавица/зёзалица ж. покр. 'бела плиска' Далмација, Гружа (РСАНУ)

с.-х. зѐза̄љка ж. покр. 'бела плиска' Хирц, Зоруновац (РСАНУ)

c.-x. zeza f. 'vrsta ptice' [Motacilla alba] (RJAZU)

c.-X. zezalica i zezaljka f. Isto što i zeza. Matevac kod Niša (RJAZU)

c.-x. zezavka f. Isto što zeza. repomiga, zezavka, tegarica, tresorepka (RJAZU)

c.-х. зе́заљћа ж. 'птица бела плиска, Motacilla alba' Тимок (Динић 2008)

c.-х. чак. zênzulica 'Motacilla alba' Strped u Istri, zènzalica 'id.' Oprtalj u Istri (Vinja 3: 320-321).

\subsection{3 'МАЛИ ЈАСТОГ'}

с.-х. зёзало с. покр. 'врста малог јастога' Корчула (РСАНУ)

c.-X. zèzalo n. 'mala vrsta račića': Zezalo je sitan račić (jastožić) između gamadi. Zore. Zezalo, vrlo mali jastog, što se nađe među gerama, dug kao prst ali nema roga kao jastog. Slovin. (RJAZU)

c.-x. zèzalo n. Žirje, Požura, Mokošice, pōzezalo Sevid; zênzalo Račišće, Žuljana, Duba 'batikul, Scyllarus arctus' (Vinja 3: 320-321)

c.-x. zèzavac m. 'batikul, Scyllarus arctus' Tkon, Krapanj, Rogoznica, Podgora (Vinja 3: 320-321).

\subsection{4 'КРМАЧА'}

с.-х. зёза ж. покр. 'име крмачи' Славонија (РСАНУ).

\section{8 'ТРТЉАТИ'}

слн. zazljáti $=$ sasljati 'im Reden mit der Zunge anstoßen Mur.; 'wispeln’ Jan.; säuseln’ M. (Pleteršnik 1895)

слн. zezljáti, -am redko 'nepravilno izgovarjati glasove c, z, s ali z njimi zamenjavati č, ž, š; sesljati’ (SSKJ).

\subsection{1 'ОСА (или ЦВРЧАК)' 14}

с.-х. зе́заљка ж. 'мала, танка осица' (Cicada [цврчак]) Тимок (Кожељац 2014).

\section{3 ОНОМАСИОЛОШКЕ ПАРАЛЕЛЕ}

Ономасиолошке паралеле комплетном инвентару значења глагола зезати (ce) (§ 2.1 до 2.8.1) колико нам је познатно, не постоје. Али делимичних има више, већ међу најближим синонимима - почев од самог мрдати. Указујемо на неке:

14 Алтернативни денотат потиче од лат. cicada, које сам Динић даје у оквиру своје дефиниције. 
[1] За помак $2.1 \rightarrow 2.3$ уп. с.-х. мрдати : с.-х. покр. mrdati 'futuere' (RJAZU).

[2] За помак $2.3 \rightarrow 2.6,2.5$ уп. с.-х. јебати : с.-х. колокв. зајебавати (се).15

[3] За помак $2.1 \rightarrow 2.4$ уп. с.-х. мрдати : с.-х. покр. mrdati 'šeprtljiti tj. raditi nevješto’ (RJAZU).

[4] За помак $2.1 \rightarrow 2.6$ уп. с.-х. махати : с.-х. замајавати (се), или с.-х. витлати : с.-х. завитлавати (се).

[5] За помак $2.1 \rightarrow 2.7 .4$ (или *2.7.1.1), уп. слн. mrdati : слн. mrda 'гримаса; птичја тртица'.

[6] За помак $2.1 \rightarrow 2.3$ уп. с.-х. тртати : с.-х. тртити .

[7] За помак $2.1 \rightarrow 2.7 .1$ уп. с.-х. тртати : с.-х. тртищза.

[8] За помак $2.1 \rightarrow 2.8$ уп. с.-х. тртати : с.-х. тртљьати.16

\section{4 ИНОСЛОВЕНСКИ ПАНДАНИ}

Породица речи јсл. zezati (se) / зезати (ce) тешко се, на основу расположивих речника, може увећати - не само на ширем словенском терену већ ни у првом суседству, на његовом југоистоку. Стога о сличним (сазвучним и блискозначним) речима у осталим словенским језицима говоримо као о панданима пре него паралелама.

4.1 Тако нпр. буг. зйзна 'треперя от студ'17 семантички стоји сасвим близу основном значењу (в. § 2.1) али формално не одговара јер му се коренски вокал не може изводити од псл. *-e-, чак ни од псл. *-e- (већ од псл. *- $\left.{ }^{*}\right) .18$ Иста формална потешкоћа постоји и у облику са звучном ономатопејом, зъзинка дијал. '(за пчела) бръмчи' (БЕР 1: 663), додатно потенцираном назалним ин-

15 Уп. и пример: Зезају га у здрав мозак. Каменица код Ниша (Јовановић 2004), иначе у широкој колоквијалној употреби.

16 За податке о последња три помака уп. Skok 3:51 s.v. trtati 'климати ce, треперити; тетурати се', тамо и trteljiti 'скакутати'. Питање је да ли је он у праву по питању примарности ономатопеје (по њему, „trt [se] prenosi sa mucanja na nesiguran hod“). Нарочито је нејасно да ли треба раздвајати одреднице trt (3: 510) и trtati (3: 511), и да ли овој другој припада trta 'дебељко'. Највећа дилема тиче се оправданости смештања именице trtica s.v. trta 'чокот лозе' само на основу семантике избочености тог дела тела код птица! По нама, именовање према том детаљу (није то једина избочина) мање је вероватно него номинација према функцији тог дела дела: с.-х. зез(ак) од зезати, односно слн. $m r d a$ од $m r d a t i$ пружају одличне ономасиолошке паралеле за извођење тртица од тртати.

17 Ова књижевна реч без породице речи само се кратко описује као ономатопеја (БЕР 1: 663).

18 Други ономатопејски глагол, буг. зъзъка '(за шурец) свири', могао би бити и грецизам,

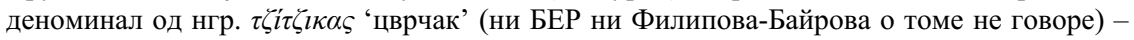

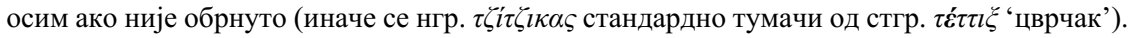


фиксом и деминутивним формантом -к- (за аналогију овом последњем уп. с.-х. чак. zezukati ‘коитирати’ у § 2.3).

4.2 Даље везе, нпр. буг. зъзъेнка '(за пчела) брьмчи' са рус. дијал. зезл 'улей’, које је и само хапакс (СРНГ 11: 244), још су мање извесне (пре је у питању случајност него сродност), мада тај руски облик, са коренским вокалом -e- (а не -я-, које би рефлектовало евентуално псл. *-e-), осим разумне семантичке блискости, за јсл. zez- представља добар формални корелат, а за слн. zezljáti (в. § 2.8) чак и семантички. Са друге стране, у истом семантичком кругу звучне ономатопеје, а формално одговарајуће јужнословенском zezati (se) / зезати (се), стоји рус. дијал. зезу́ля 'кукушка, Cuculus L.' са дублетом зозу́ля 'исто’ (СРНГ 11: 326, уП. и укр. дијал. зозу́ля, блр. зязюля ‘исто’). Преко другог значења зозу́ля 'пьяница' (СРНГ 11: 326) отвара се веза са рус. дијал. зо́за 'неаккуратный, немытый, грязный человек' (као потенцијално чистим поствербалом непосведоченог глагола *зезать, чак са регуларним прегласом, где вербалном е одговара номинално o). Свака правилност се губи када се узму у обзир варијанте орнитонима рус. дијал. зюзю́я 'кукушка, Cuculus L.' и зязюля 'исто' (СРНГ 12: 42, 49). На синхроном плану, као синоними са експресивном варијацијом, ту би даље могли спадати и дијалектизми као зюзю́ка ‘картавый, шепелявящий человек' (уп. § 2.8), или зюзя 'человек который много пьет, неряха', зюзик 'зевака, нерасторопный человек' (уп. § 2.4), зю́зга 'поросенок' (уп. § 2.7.4) и др. (в. СРНГ 12: 42-43). И најзад, сасвим је неизвесна веза побројаних облика са синонимним паром рус. дијал. за́зга = зи́зга 'забота, хлопоты': Эта работа дала мне зазги; без всякой зазги/зизги (СРНГ 11: 91, 271), за семантику уп. $§ 2.4$.

4.3 Детаљан попис и формално-семантичка класификација барем источнословенских дијалекатских облика од основа зез-, зоз-, зиз-, заз-, зяз-, зюз- итд. (налик ономе што је своједобно на широком словенском плану дао Толстой 1978 за основу geg- и њене варијације са gig-, gog-, gag-)19 били би добра основа за поређење тог корпуса са овде приказаним јужнословенским. Док се тај материјал не сакупи као критична маса за извођење боље утемељених закључака, овде наведене везе остају само као назнаке.

\section{5 ЕТИМолоГИЈА}

Етимологија јсл. глагола zezati (se) / зезати (ce) досад је разматрана једино у словеначком великом етимолошком речнику (в. Bezlaj 4: 407, аутор одреднице Метка Фурлан), одакле је тумачење преузето у SNB (2013: 400).

19 Драгоцени резултат је то што је показано како ти облици не подлежу I палатализацији. Детаљније само о с.-х. гѐzати (се) в. Bjeletić - Vlajić-Popović 1993. 
5.1 Тамо предложено извођење јсл. zezati (од псл. *zęzati, као сродног са лит. žeñgti, žengiù 'корачати', лет. ziegtiês 'преступити, згрешити', преко којих би, заједно са гот. gaggan, срвнем. gangan итд. он могао да рефлектује пие. *ǵhengh- 'корачати, ићи') није сасвим уверљиво, ни формално ни семантички. Како све јужнословенске потврде потичу само из словеначког и српско-хрватског, 20 који не показују дистинкцију између рефлекса псл. *-eи *-e-, треба бити уздржан према реконструкцији јсл. *-ę- на основу два орнитонима из Истре (в. § 2.7.3) у којима назал лако може бити и секундаран. Осим тога, реконструкција псл. *zęzati, са назализованим -е̨- само на основу наводно кашупског 21 хапакса дијал. zqzelić 'uprzykrzać się komu' заправо нема основа. Осим што у тој позицији пољ. -q- регуларно рефлектује псл. *-Q- а не псл. *-e-22 (в. и случај много ближег буг. зиззна 'дрхти од хладноће' у § 4.1), овај пољ. дијалектизам не одговара јсл. глаголу пре свега својим консонантизмом, који је резултат локалног прелаза $\dot{z}>z$ (тзв. „mazurzenie“, в. Brückner 647) и заправо се своди на пољ. *żqzel. Даље балтске паралеле пољ. облика и крајње ие. порекло нису спорни, али наш глагол са њим(а) није сродан. Осим тога, указивање на обострани семантички паралелизам ‘корачати' и ‘тући' није релевантно јер глагол *zęzati у основи нема ниједно од та два значења већ само 'мрдати, треперити, њихати, махати и сл.'. Све су то значења која приличе једном ономатопејском глаголу (уп. и богати материјал из источне Србије). Управо ономатопејска природа јсл. zezati (se) / зезати (се) оправдава идеју да се он доведе у директну везу са слн. zezljáti ‘фрфљати, шушкати’ (в. Bezlaj 4: 407 s.v.) што би било мање вероватно да је у питању „обичан“ глагол кретања. За друге могуће реализације звучне ономатопеје, в. $§ 2.8 .1$ (даље и $§ 4.2$ ).

5.2 Оно што нарочито приличи једном ономатопејском глаголу јесте да буде деривациона база назива за карактеристичну птицу 'Motacilla alba', зёза, зѐза̄љка и сл. С обзиром на све синониме тог орнитонима који су мотивисани мрдањем и тресењем (в. § 2.7.2), као и на чињеницу да се ареал орнитонима у потпуности поклапа са ареалом глагола zezati (se) / зезати (ce), од Алпа и Истре до Ниша (али не даље!, в. § 2.7.2), нема места сумњи у њихову сродност. Исто се односи и на друге девербале: 'тртица' (в. § 2.7.1), 'јастог' (в. $§ 2.7 .3)$, ‘крмача (или њена њушка)’ (в. § 2.7.4), без обзира на мању

20 Буг. зиззна 'дрхти од хладноће' (в. § 4.1) тамо и није узето у обзир.

21 Питање је да ли је овај облик заиста кашупски, будући да га не региструје ни описни ни етимолошки речник тог језика, нити Stownik gwar kaszubskich na tle kultury ludowej Bernarda Sychte (t. 6, Wrocław etc.: PAN, 1973) нити Stownik etymologiczny kaszubszczyzny W. Borysia и Н. Popowske-Taborske (t. 5, Warszawa: PAN, 2006). Brückner га 1927. године, у складу са својим временом, није могао третирати другачије него као пољски дијалектизам.

22 Уп. пољ. $z a b<$ псл. *zobъ, али пољ. $\dot{z} q \dot{c}<$ псл. *žęti, пољ. żqdać < псл. *žędati. Тако би се пољ. *żążel (када би постојало) изводило од псл. **žęžel'b а не од **zęzel’b. 
фреквентност њихових потврда и различито простирање њихових изоглоса23 у оквиру ареала дефинисаног глаголом и орнитонимом.

\section{6 ЗАКљУЧАК}

На основу изложеног материјала треба закључити да етимологија јсл. zezati (se) / зезати (ce) 'мрдати (ce) итд.', у одсуству поузданих инословенских, 24 па самим тим и вансловенских паралела, остаје нејасна - осим што се он са великом сигурношћу може сматарати ономатопејским. Иако се сви наведени примери своде на једно *zezati (se), засад нема довољно основа да се говори о прасловенској старини тог глагола - чак ни на нивоу позног прасловенског дијалектизма. Евентуални нови налази из других језика (в. § 4.3) могли би битно да промене ту ситуацију.

\section{ЛИТЕРАТУРА}

Андрић $=$ Драгослав Андрић, Речник жаргона, Београд: Zepter Book World - Драгослав Андрић, 22005.

БEP $=$ Български етимологичен речник 1-, София: БАН, 1971-.

Бјелетић - Влајић-Поповић 2013 = Марта Бјелетић - Јасна Влајић-Поповић, Једнотомни етимолошки речник српског језика (методолошки аспект), Зборник Матище сриске за славистику 83 (2013), 171-180.

Вук 1818 = Вук Стефановић [Караџић], Српски рјечник, Беч, 1818.

Динић 1992 = Јакша Динић, Речник тимочког говора (други додатак), Српски дијалектолошки зборник 38 (1992), 381-586.

Динић 2008 = Јакша Динић, Речник тимочког говора, Београд: Институт за српски језик САНУ, 2008 (Монографије 4).

Кожељац 2014 = Љубиша Рајковић Кожељац, Речник тимочког говора, Неготин: Књижевно издавачко друштво Лексика, 2014.

PMCMX = Речник српскохрватског књижевног језика 1-6, Нови Сад: Матица српска - Загреб: Матица хрватска, 1967-1976.

PСАНУ = Речник српскохрватског књижевног и народног језика 1-, Београд: Институт за српски језик САНУ, 1959-.

PCJ 2007 = Речник српског језика, Нови Сад: Матица српска, 2007.

РСгВ = Речник српских говора Војводине 1-10, Нови Сад: Матица српска, 2000-2010.

Станић 1990-1991 = Милија Станић, Ускочки речник 1-2, Београд: Народна књига, 19901991.

23 Преко 'тртица' се везују Штајерска и Војводина, 'јастог' се простире дуж обале Далмације, а 'крмача' је само у Славонији.

24 На нимало ретко одсуство података из других језика овде се надовезала једна необична чињеница: етимологија обично нема додирних тачака са социолингвистиком, али у случају глагола зезати (ce) она се умешала као ванлингвистички фактор пуританства и лишила нас незнаног броја потврда које су не само старији лексикографи, већ и новији записивачи, аутоцензуром изабрали да не уврсте у своје пописе. О погубности такве праксе говори чињеница да је међу двестотинак пунктова за РСГВ, само на једном месту, у Новом Милошеву, посведочен глагол зезати (ce) и то са целом породицом (укљ. драгоцено хапаксно значење 'доњи део кичме' = 'тртица'). То није одраз реалног стања него (ауто)цензуре. 
Толстой 1978 = Н.И. Толстой, О непоследовательности первой палатализации славянских задненебных согласных, Linguistica XVII (1978), 33-47.

Марковић 1986 = Миодраг Марковић, Речник народног говора у Црној Реци, Српски дијалектолошки зборник 32 (1986), 243-500.

Anić = Vladimir Anić, Veliki rječnik hrvatskoga jezika, Zagreb: Novi Liber, ${ }^{42003 .}$

Bezlaj = France Bezlaj, Etimološki slovar slovenskega jezika 1-5, avtorji gesel France Bezlaj- Marko Snoj - Metka Furlan, Ljubljana: SAZU - ZRC SAZU, 1976-2007.

Bjeletić - Vlajić-Popović 1993 = Marta Bjeletić - Jasna Vlajić-Popović, On Serbo-Croatian verb gegati se 'to stagger', Linguistique balkanique 36 (1993), № 2, 93-99.

Brückner $=$ Aleksander Brückner, Stownik etymologiczny języka polskiego, Warszawa:Wiedza Powszechna, ${ }^{2} 1957$ [= Kraków: Krakowska Spółka Wydawnicza, $\left.{ }^{1} 1927\right]$.

ČDL = Mate Hraste - Petar Šimunović - Reinhold Olesch, Čakavisch-deutsches Lexikon I, Köln Wien: Böhlau, 1979.

Jurančič 1981 = Janko Jurančič, Slovensko-srbskohrvatski slovar, Ljubljana: DZS, 1981.

Lipljin 2002 = Tomislav Lipljin, Rječnik varaždinskoga kajkavskoga govora, Varaždin: Garestin, 2002.

Pleteršnik 1894-1895 = Maks Pleteršnik, Slovensko-nemški slovar 1-2, Ljubljana: Knezoškofijstvo, 1894-1895.

RJAZU = Rječnik hrvatskoga ili srpskoga jezika 1-23, Zagreb: JAZU, 1880-1976.

Sabljak = Tomislav Sabljak, Rječnik šatrovačkog govora, Zagreb: Globus, 1981.

Skok = Petar Skok, Etimologijski rječnik hrvatskoga ili srpskoga jezika 1-4, Zagreb: JAZU, 19711974.

SNB = Slovar novejšega besedja slovenskega jezika, Ljubljana: ZRC SAZU, 2013.

SSKJ = Slovar slovenskega knjižnega jezika 1-5, Ljubljana: DZS, 1970-1991.

Šimunović 2006 = Petar Šimunović, Rječnik bračkih čakavskih govora, Supetar: Brevijar, 2006.

Večenaj - Lončarić 1997 = Ivan Večenaj - Mijo Lončarić, Rječnik Gole, Zagreb: Institut za hrvatski jezik i jezikoslovlje, 1997.

Vinja = Vojmir Vinja, Jadranske etimologije: jadranske dopune Skokovu etimologijskom rječniku 1-4, Zagreb: HAZU - Školska knjiga, 1998-2016.

\section{PovZETEK}

\section{Jsl. zezati (se) - leksikografska sirota ali legitimno geslo}

Prispevek semantično, onomaziološko in etimološko analizira glagol zezati se 'šaliti se (nevtralno ali grobo), zast. pokr. 'gibati; spolno občevati itd.' z izpeljankami, ki se nahajajo v slovenskih in srbsko-hrvaških razlagalnih, narečnih in etimoloških slovarjih. Naša semantična klasifikacija je dala osem osnovnih pomenskih skupin glagolov ter samostalnikov: od morda osnovnega 'migati' (s premiki proti 'udariti, treščiti', 'spolno občevati', 'trudoma delati ali hoditi', 'varati in/ali mučiti', 'spolno občevati', 'nagajati', 'blebetati'), glavna samostalnika pa sta $z e z$ 'trtica' in ornitonim zeza 'bela pastirica', potrjena $\mathrm{v}$ obeh jezikih (tudi zezalo 'mali jastog', zeza 'svinja', zezaljka 'osa [ali škržat]' samo v sr.-hr.). Podani semantični spekter ima vrsto onomazioloških paralel. Povsem ustrezajočih podatkov iz drugih slovanskih jezikov ni (ali so vsaj še neznani), navajajo se nekateri nasprotki z različnim, ekspresivno spremenljivim vokalizmom in bolj ali manj tekočim semantičnim zaporedjem. Obstoječa etimološka interpretacija (Bezlaj 4: 407) ni dovolj trdna, zato je na mestu predlog, da se etimologija tega onomatopejskega glagola do skrbne proučitve bolj popolnega slovanskega gradiva šteje za nejasno. 